\title{
ETHICAL ISSUES IN THE ASSESSMENT OF SPEAKING SKILLS
}

Language assessment is a rather complex yet an inseparable part of the learning process. Not only should it represent learners' achievements, but it also ought to facilitate and enhance learning. Assessing spoken proficiency can be regarded as particularly difficult, complex, and time-consuming since many aspects of oral performance need to be carefully considered. The two types of assessment, the assessment for learning (formative assessment) and the assessment of learning (summative assessment), have to be taken into account as they both occupy a significant role in the overall development of speaking skills of a learner. However, mastering the formal and informal kinds of assessment requires considerable expertise, hard effort, and invaluable experience. Therefore, EFL teachers often fail in their attempt to conduct a proper and fair assessment of speaking skills. Moreover, the question of ethics, which represents an important element of the assessment process, is frequently neglected too. This paper discusses ethical issues in the assessment of spoken proficiency of EFL learners. Furthermore, ethical obligations EFL teachers ought to comply with in terms of the Communicative approach are also explored.

Keywords: formative and summative assessment, ethical aspects, speaking skills, EFL learner, EFL teacher

\section{Introduction}

Speaking is one of the four language skills (listening, reading, writing, speaking) which English language learners need to master if they wish to become efficient users of the language. Listening and reading are receptive skills, while speaking and writing can be considered productive skills. T. Farell [1] maintains that it is more difficult to speak a language than read or listen to it. Similarly, assessing speaking can be deemed to be more difficult and complicated in comparison to the evaluation of reading or listening. Therefore, English teachers need to take plenty of aspects into account if they wish to teach and test oral skills effectively and appropriately.

The first part of the article discusses the process of teaching speaking skills. Moreover, the microskills of speaking are introduced, and providing learners with sufficient space to speak is emphasized. The second part examines how the skill of speaking ought to be assessed from the standpoint of formative and summative types of assessment. Both parts of the paper take, among other features, ethical aspects into consideration.

\section{Teaching speaking}

The skill of speaking can be regarded as a primary skill in English as a foreign language (EFL) teaching [2], [3]. People who possess the knowledge of a language are often referred to as speakers of that language. Furthermore, the primary aim of the majority of learners is to be able to communicate in a foreign language. Therefore, teaching speaking skills ought to be in the foreground of the EFL teaching and learning process. On the other hand, it is important to mention that speaking is possibly the most difficult of the four skills [4]. While it is necessary that EFL learners demonstrate the knowledge of grammar, vocabulary, and language functions, it appears that such knowledge is not enough [5]. Mastering the skill of speaking is a rather complex and difficult issue, and apart from grammar, vocabulary, and pronunciation, it involves a number of aspects - the so-called speaking subskills (microskills), which actually form the overall competence of spoken proficiency of an individual [6]. D. Brown [7, p. 272] mentions these microskills of oral communication of a learner:

- produce chunks of language of different lengths;

- orally produce differences among the English phonemes and allophonic variants;

- produce English stress patterns, words in stressed and unstressed positions, rhythmic structure, and intonational contours;

- produce reduced forms and words and phrases;

- use an adequate number of lexical units (words) in order to accomplish pragmatic purposes;

- produce fluent speech at different rates of delivery;

\footnotetext{
* Rastislav Metruk

Department of English Language and Literature, Faculty of Humanities, University of Zilina in Zilina, Slovakia

E-mail: rastislav.metruk@fhv.uniza.sk
} 
- monitor your own oral production and use various strategic devices - pause, fillers, self-corrections, backtracking - to enhance the clarity of the message;

- use grammatical word classes (nouns, verbs, etc.), systems (e.g. tense, agreement, pluralization), word order, patterns, rules, and elliptical forms;

- produce speech in natural constituents - in appropriate phrases, pause groups, breath groups, and sentences;

- express a particular meaning in different grammatical forms;

- use cohesive devices in spoken discourse;

- accomplish appropriately communicative functions according to situations, participants, and goals;

- use appropriate registers, implicature, pragmatic conventions, and other sociolinguistic features in face-toface conversations;

- convey links and connections between events and communicate such relations as main idea, supporting idea, new information, given information, generalization, and exemplification;

- use facial features, kinesics, body language, and other nonverbal cues along with verbal language to convey meanings;

- develop and use a battery of speaking strategies, such as emphasizing key words, rephrasing, providing a context for interpreting the meaning of words, appealing for help, and accurately assessing how well your interlocutor is understanding you.

Most of the English language teachers would probably agree that there also exist other subskills. These microskills prove that the speaking skill is indeed a complex and difficult to master, and the question of how EFL learners ought to acquire and practice the subskills needs to be addressed.

Traditional methods of teaching such as the grammartranslation method paid only little or no attention to speaking (and listening) activities [8]. Furthermore, almost no attention was devoted to pronunciation [9], which is a vital component of spoken proficiency. In connection with this, L. Mocova [10] explains that successful communication (also) depends heavily on stress, rhythm, intonation, and appropriate pronunciation of sounds.

When the Communicative approach (Communicative language teaching) came into being, a shift in English language teaching occurred. Language learning moves from explicit, declarative knowledge (e.g. grammar rules, forms, or vocabulary) to its proceduralization (acquiring implicit knowledge), which means that the learners ought to be able to use language automatically as well as creatively when needed [11]. "In other words, learners do not need to be able to talk about grammar but they need to be able to use it for communicative purposes" [12, p. 31]. Taking the four skills into consideration, "Communicative language teaching emphasizes speaking and listening rather than reading and writing" $[13$, p. 150$]$.
If EFL learners are to become efficient speakers of English, teachers should adhere to the principles of the Communicative approach. One of the principles underlines the importance of providing learners with sufficient space for developing the skill of speaking. It is obvious that improving one's speaking ability is not easy when a learner does not have ample opportunity for practicing speaking in the target language (numerous theorists believe that using L1 in the English language lessons blocks and slows down the acquisition of L2 [14]).

Traditional teacher-centered approaches focused on the teacher instead of on the learner, and it was the teacher who did the most of the talking while students merely listened [15]. "Although it may sound like a cliche, learner-centred instruction/ education has been proved as indisputably more effective compared to teacher-centred education" [16, p. 46]. However, the learner-centred approach may not always be applied in Slovak schools. "When observing classes in mainstream schools (state schools), analysing educational results (e.g. PISA) and various classroom research findings, it is obvious that traditional teaching approaches are still dominant" [17, p. 31].

Modern teachers of English need to make sure that they have abandoned the traditional teacher-centered approaches. Moreover, they have to give their learners a chance to master a variety of subskills. Providing the learners with little or no space to develop their speaking microskills might be even regarded as unethical since it is the learner who needs to speak at English lessons. Although English language teachers represent a source of input, increasing the student talking time seems to be of paramount importance. Working in pairs and small groups will possibly result in such an increase. "Pair and group work are the most effective way of increasing students' talking time" [18, p. 55]. Teachers have to bear in mind that it is their learners who need to develop and improve their speaking skills. Therefore, the active learners who have plenty of opportunities to speak, ought to be in the foreground of the teaching process.

\section{Assessing speaking}

Speaking is regarded as the most difficult skill to assess [19]. A. Lazaraton [20, p. 106] states that "[i]t is certainly not a coincidence that speaking is also perhaps the most perplexing of the traditional four skills to assess." Assessors need to decide on which subskill(s) they will concentrate on at the moment of assessment, relying on their memory or the notes they have taken.

D. Gondova [21] explains that there exist two types of assessment, depending on how it is carried out and what its goals are, namely assessment for learning (formative assessment) and assessment of learning (summative assessment).

The formative assessment is typically conducted throughout a course or project, and it is used to facilitate and enhance learning. This type of assessment can be performed by a teacher or 
Table 1 An Example of Assessment Criteria for Speaking

\begin{tabular}{llll}
\hline \multicolumn{2}{l}{ Accuracy } & Fluency & Pronunciation \\
\hline 5 & $\begin{array}{l}\text { Grammatical and lexical accuracy extremely } \\
\text { high. }\end{array}$ & $\begin{array}{l}\text { Speaks fluently without hesitation or searching } \\
\text { for words. }\end{array}$ & $\begin{array}{l}\text { Very clear; stress and intonation help to } \\
\text { make meaning clear. }\end{array}$ \\
& $\begin{array}{l}\text { Quite accurate; some errors, but meaning is } \\
\text { always clear. }\end{array}$ & $\begin{array}{l}\text { Some hesitation and sometimes has to search } \\
\text { for words. }\end{array}$ & $\begin{array}{l}\text { Generally clear; reasonable control of stress } \\
\text { and intonation. }\end{array}$ \\
3 & $\begin{array}{l}\text { Frequent errors; meaning is not always } \\
\text { clear. }\end{array}$ & $\begin{array}{l}\text { Quite hesitant; limited range of vocabulary } \\
\text { and structures. }\end{array}$ & Frequent errors; not always clear enough to \\
& $\begin{array}{l}\text { Very frequent errors; difficulty in making } \\
\text { meaning clear. }\end{array}$ & $\begin{array}{l}\text { Extremely hesitant; very limited range of } \\
\text { language available. }\end{array}$ & Very frequent errors; often very difficult to \\
& Almost unable to communicate. & & understand.
\end{tabular}

a peer providing feedback on a student's work, and is not normally graded [22]. Feedback is considered to be a principal component of the assessment for learning. It is important to remember that the formative assessment represents a developmental way of evaluating the progress towards a specified objective [23]

"The main function of assessment for learning is to reflect the learning process and give learners some information on their progress throughout a course, which helps them become more efficient" [21, p. 13]. According to S. Brookhart [24], the research into the formative type of assessment confirms that when the appropriate formative assessment is conducted and learners take part in it, both achievement and motivation enhance.

The summative assessment, on the other hand, represents a more formal way of testing students' knowledge, and is typically used at the end of a unit or a semester [25]. A. Benjamin [26, p. 3] takes the view that " $[w]$ hen we think of summative assessments, we think of unit tests, final exams, standardized tests, entrance exams, and the like". The summative assessment ends with a grade.

Plenty of criteria may be used for speaking assessment, depending on which subskills teachers want to test. These are the most common ones [21, p. 162]:

- appropriateness;

- organization of ideas;

- fluency;

- grammatical accuracy and the range of grammatical structures;

- the range of vocabulary and its accuracy;

- content;

- pronunciation and intonation;

- interaction.

M. Spratt, A. Pulverness and M. Williams [27, p. 108] provide the following example of assessment criteria for speaking. This is the so-called analytical way of scoring as far as the summative assessment is concerned. The criteria are arranged as a set of bands, and they describe different levels of ability. Learners can be awarded the maximum of five points for each criterion. The example is illustrated in Table 1.
The difference between the formative and summative assessments can be exhibited by the following analogy by Robert stake, an evaluation researcher: "[w]hen the cook tastes the soup, that's formative; when the guests taste the soup, that's summative" [cf 28, p. 117]. It is, however, vital to mention that both types of assessment have their place in the EFL teaching, and ought to be used within the assessment of speaking skills.

\section{Ethical aspects when conducting formative assessment}

The question of ethical aspects within the assessment of speaking skills should to be discussed too. If the formative assessment is conducted inappropriately, the question of correctness and fairness arises.

For example, EFL learners are asked to practice speaking - first, they are required to read an article about the immediate impact of drinking beverages of various temperature on a human body and, subsequently, they are asked to give their opinions on whether or not they agree with the statements in the text and why. The text, among others, contains adjectives that describe temperature (cold, cool, hot, boiling, warm, etc.), so it is highly likely that some of the adjectives will be used in the discussions. While working in pairs, the teacher, having assumed the role of an observer, notices that some of the learners pronounce the word hot as [ha:t]. Pronouncing hot as [ha:t] refers to the American way of pronouncing this word, while [hpt] is predominantly used by British speakers [29], [30]. Afterwards, while giving feedback and performing the formative type of assessment, the teacher points out that the word hot ought to be pronounced as [hpt], not as [ha:t] since both the learners and teachers "should" use British pronunciation instead of the General American (GA) pronunciation (standard American pronunciation). It should be noted that the British standard of English pronunciation (also called the BBC accent) is a pronunciation variety which is offered by the majority of EFL textbooks in Slovakia, and many teachers try to speak with this accent. Moreover, most of the learners pronounce the word warm as [wo:rm] and toasty as ['torsti] 
during their speaking practice (pronouncing the two words with the GA accent). However, this time the teacher "fails to correct" the learner's GA pronunciation as they do not explain to the learners that in the $\mathrm{BBC}$ accent, the word warm is pronounced as [wo:m] and the word toasty as ['tərsti]. Therefore, one burning question, which remains unanswered, needs to be tackled. Why did the teacher point out the GA pronunciation of the word hot, but did not call attention to the GA pronunciation of the words warm or toasty (the three words have been used on numerous occasions during the activity by the students)? All three instances represent characteristic examples of the key differences between the segmental systems of the BBC and GA accents.

Perhaps the teacher's lack of knowledge of English phonetics is responsible for not mentioning all three examples. If this is the case, several questions with regard to the correctness and fairness arise. Is it appropriate to "correct" the pronunciation of learners when teachers themselves are not familiar enough with the subject matter they have brought up? Is it fair to demand that the learners of English use only one variety of pronunciation, although the vast majority of both EFL learners (and teachers) are not able to use only one accent consistently, and normally use the mixture of the two varieties? Is it proper to focus on the differences between the $\mathrm{BBC}$ and $\mathrm{GA}$ accents when the primary goal in EFL pronunciation is to achieve clear, intelligible pronunciation with reduced L1 (mother tongue) accent? The answers to the questions are not clear and straightforward, and convincingly demonstrate the complexity of teaching oral skills as well as the intricacies of providing learners with constructive, useful, and favorable feedback on speaking when conducting the formative assessment. Therefore, EFL teachers should strongly consider a substantial number of questions before performing the assessment for learning.

It should be also emphasized that the example above involved only one (the subskill of pronunciation) of the many speaking microskills EFL learners need to master if they wish to become efficient speakers of English.

\section{Ethical aspects when conducting a summative assessment}

There are normally two examiners who perform the formal assessment of speaking skills. One of them is interlocutor and the other one assessor. The interlocutor is an examiner who asks questions, interacts with a candidate, measures time, and the like [31]. The assessor, on the other hand, does not talk to the candidate, and thus has time to take notes and perform the analytical scoring of speaking performance of a candidate on the basis of selected criteria. There are, however, numerous instances when one or both examiners fail to carry out a fair and proper assessment. The following selection of examples illustrates the possible pitfalls of assessing the speaking skills.

\subsection{Testing knowledge instead of speaking skills}

When teachers assess speaking skills, they need to remember that they should actually test how well their learners have mastered particular speaking subskills, not the knowledge about various topics. Although a wide range of topics is frequently used when testing the speaking, it must be emphasized that the tasks and questions have to be opinion-based, and that they are within the scope of a general student's knowledge. Knowledge-based topics primarily measure the information and understanding learners have about a particular topic. If candidates do not possess such knowledge, they do not speak, and it is not possible to measure their speaking skills.

\subsection{Testing memorizing and reciting}

Memorizing and reciting a text can be deemed a recurring problem concerning the evaluation of spoken proficiency. For example, after a student is told which topic they are going to talk about, they immediately, without being asked a single question or given a task, start reciting what they have learned by heart about the topic. The teacher often lets the student talk for minutes, and then possibly asks the candidate one or two additional questions. Once the recital is finished, teacher awards the student with a high grade. This is an example of serious professional misconduct as far as assessing speaking skills is concerned. Memorizing a text and reciting it tests rather a memory of a candidate or how well they have learned something by heart. It has nothing to do with testing the spoken proficiency of an English language learner. Candidates can be, however, given some time for preparation, but they should not be given any direct questions beforehand.

\subsection{Halo effect and order effect}

Assessing the spoken proficiency may be negatively influenced by the so-called halo effect. This term represents the influence of knowledge and information a teacher has about a candidate for the evaluation of the candidate's speaking skills. In connection with this, R. Wright [32, p. 213] maintains that " $[t]$ here is a real tendency for our expectations of students to color our evaluations of their work. Those students who did well in the past are expected to continue, while those who have had low test scores in the past are anticipated to continue that way in the future". For example, if a teacher considers a candidate to be a brilliant, straight-A student, it is likely that the teacher's expectations can be too high. Therefore, if such a student does not perform on a high level (as they normally do), the teacher may award them with a lower grade - for instance, the grade $\mathrm{C}$, despite the fact that the candidate has met the criteria according to which they should be perhaps given a $\mathrm{B}$. 
Order effect can negatively affect the evaluation of speaking performance too. When an examiner experiences an outstanding speaking performance of a candidate, they are likely to evaluate the performance of the following candidate more strictly. Alternatively, if a candidate's performance is rather poor or unsatisfactory, there is increased likelihood that the assessor will be less strict with the next candidate. It must be remembered that when assessing speaking skills, students should not be compared with each other, but their performances ought to be assessed against the set of criteria [21].

\subsection{Principles of assessment - making the criteria clear to the students}

There has been a general tendency to evaluate candidates' performance without making the assessment criteria clear to them. The research conducted in the last 20 years demonstrates that there are various principles which ought to be applied in the assessment settings so that the assessment can become clearer, fairer, more equitable, and more transparent to the learners [32]. These are the factors teachers should take into consideration as far as assessing speaking skills is concerned [33, p. 259]:

- students should be informed when they are being assessed;

- students should be informed how they will be assessed;

- teachers should make the criteria for assessment explicit to the students;

- the ratings, scores, marks, or grades attached to the criteria should be explained to students.

Teachers have to bear in mind that if their learners do not know when, how, according to which criteria and way of scoring they are going to be assessed, the assessment process is negatively influenced and, its importance and reliability decrease. Furthermore, it does not seem correct and fair to the students not to inform them in advance about the above-mentioned factors.

\subsection{Assessing only the subskills of grammar and vocabulary}

It is not always the case that examiners also concentrate on other subskills than grammar and vocabulary. Although these two language systems constitute a significant part of overall speaking proficiency, the evaluation of other microskills seems inevitable. It should be noted that candidates can achieve the goal of spoken communication even if they make grammatical and lexical errors to a certain degree. Thus, they may succeed in communication, and failing them due to such mistakes would not seem appropriate.

It seems reasonable to assume that errors in grammar and vocabulary which cause communication breakdowns should be evaluated more strictly in comparison to minor errors. On the other hand, if a learner fails to answer the questions of an examiner, is not fluent enough, their pronunciation is difficult to understand, or does not react to the questions appropriately, the candidate ought to be assessed in a negative way, although they have only made a negligible amount of grammatical and lexical errors.

The above-mentioned instances are only few examples of inappropriate evaluation of speaking skills which should be taken into account by EFL teachers in order to test the speaking skills as correctly and appropriately as possible.

\section{Conclusion}

Teaching and testing speaking represent a complicated and complex matter. It must be emphasized that EFL teachers do not follow grammar-translation approaches anymore, but adhere to the principles of Communicative language teaching. Moreover, it is imperative that both teachers and learners are well aware of various subskills that need to be developed, and that the learners are provided with a lot of opportunities for practicing these microskills of speaking, participating primarily in pair work and group work activities.

As far as testing the speaking skill is concerned, both the assessment for learning and the assessment of learning are of profound importance, and have to be incorporated into the teaching/learning process. EFL learners need to receive helpful and positive feedback as often as possible when it comes to formative assessment. EFL teachers have to avoid a variety of obstacles they are likely to experience when assessing speaking summatively. Therefore, they ought to understand the complexity and seriousness of summative assessment so that they are able to conduct this type of evaluation in a reasonable, correct, and proper manner.

\section{References}

[1] FARELL, T.: Succeeding with English Language Learners. A Guide for Beginning Teachers. Corwin Press, Thousand Oaks, 2006.

[2] MISHAN, F., TIMMIS, I.: Materials Development for TESOL. Edinburgh University Press, Edinburgh, 2015.

[3] UR, P.: A Course in English Language Teaching. Cambridge University Press, Cambridge, 2012. 
[4] ANDERSON, J.: Teaching English in Africa. A Guide to the Practice of English Language Teaching for Teachers and Trainee Teachers. East African Educational Publishers Ltd., Nairobi, 2015.

[5] STRAKOVA, Z., CIMERMANOVA, I.: Teaching and Learning English Language. Presovska Univerzita v Presove, Presov, 2005.

[6] MCDONOUGH, J., SHAW, C., MASUHARA, H.: Materials and Methods in ELT. A Teacher's Guide, 3rd edition. WileyBlackwell, Chichester, 2013.

[7] BROWN, D.: Teaching by Principles. An Interactive Approach to Language Pedagogy, 2nd edition. Longman, White Plains, 2001.

[8] CRYSTAL, D.: Making Sense. The Glamorous Story of English Grammar. Oxford University Press, New York, 2017.

[9] SEWELL, A.: English Pronunciation Models in a Globalized World. Accent, acceptability and Hong Kong English. Routledge, New York, 2016.

[10] MOCOVA, L.: Comparison of Slovak and English Word Stress. Communications - Scientific Letters of the University of Zilina, 14(1), 37-39, 2012.

[11] GONDOVA, D.: The Development of Speaking Skills in English Language Lessons. Communications - Scientific Letters of the University of Zilina, 14(1), 23-28, 2012.

[12] GONDOVA, D.: Using Activities as a Way of Proceduralization of Learners' Language Knowledge. Communications - Scientific Letters of the University of Zilina, 12(3), 30-34, 2010.

[13] BAILEY, K.: The Preparation and Stability of the ABE Teaching Workforce: Current Conditions and Future Prospects. COMINGS, J., GARNER, B., SMITH, C. (Eds.): Review of Adult Learning and Literacy. Connecting Research, Policy and Practice. Lawrence Erlbaum Associates, Publishers, Inc., Mahwah, p. 113-164, 2006.

[14] POKRIVCAKOVA, S.: Code-switching as a Lingvodidactic Phenomenon (in Slovak). Xlinguae, 7(2), 61-74, 2014.

[15] JONSON, K., CAPPELLONI, N., NIESYN, M.: The New Elementary Teacher's Handbook. Flourishing in Your first Year, 3rd edition. Corwin, Thousand Oaks, 2011.

[16] HANESOVA, D.: A Move toward Learner-Centred Foreign Language Pedagogy: Focusing on Factors Fostering Language Intake. Xlinguae, 8(4), 46-59, 2015.

[17] LOJOVA, G.: Humanizing English Language Teaching in Slovakia. Xlinguae, 9(4), 30-36, 2016.

[18] NUNAN, D.: Teaching English to Speakers of Other Languages. An Introduction. Routledge, New York, 2015.

[19] EKBATANI, G.: Measurements and Evaluation in Post-Secondary ESL. Routledge, New York, 2011.

[20] LAZARATON, A.: Second Language Speaking. CELCE-MURCIA, M., BRINTON, D., SNOW, M. (Eds.): Teaching English as a Second or Foreign Language, 4th edition. National Geographic Learning, Boston, p. 106-120, 2014.

[21] GONDOVA, D.: Taking First Steps in Teaching English: Assessing Learners. EDIS, Zilina, 2014.

[22] JACKSON, G.: Contemporary Viewpoints on Human Intellect and Learning. Ebook, 2010.

[23] COWIE, B.: Focusing on the Classroom: Assessment for Learning. FRASER, B., TOBIN, K., MCROBBIE, C. (Eds.): Second International Handbook of Science Education, Volume 1, Springer, Heildergerg, p. 679-690, 2012.

[24] BROOKHART, S.: Formative Assessment Strategies for Every Classroom: An ASCD Action Tool, 2nd edition. ASCD, Alexandria, 2010.

[25] CLARK, C., REAVES, S.: Together Everyone Achieves More: 33 and 1/3. The Complete Educational Process. BookBaby, 2014.

[26] BENJAMIN, A.: Formative Assessment for English Language Arts. A Guide for Middle and High School Teachers. Routledge, New York, 2013.

[27] SPRATT, M., PULVERNESS, A., WILliAMS, M.: The TKT Teaching Knowledge Test Course. Modules 1, 2 and 3. Cambridge University Press, Cambridge, 2011.

[28] PATTON, M.: Utilization-Focused Evaluation, 4th edition. Sage, Thousand Oaks, 2008.

[29] ROACH, P., SETTER, J., ESLING, J. (Eds.): Cambridge English Pronouncing Dictionary, 18th edition. Cambridge University Press, Cambridge, 2011.

[30] WELLS, J.: Longman Pronunciation Dictionary, 3rd edition. Pearson Education Limited, Essex, 2008.

[31] MILANOVIC, M. (Ed.): Multilingual Glossary of Language Testing Terms. Cambridge University Press, Cambridge, 1998.

[32] WRIGHT, R.: Educational Assessment. Tests and Measurements in the Age of Accountability. Sage Publications, Inc., Thousand Oaks, 2008

[33] GOH, C., BURNS, A.: Teaching Speaking. A Holistic Approach. Cambridge University Press, New York, 2012. 